\title{
Research on the Training Mode of Art Innovative Talents Against the Background of Sino-Russian Cooperative Education*
}

\author{
Guo Yang \\ College of Art and Design \\ Heihe University \\ Heihe, China
}

\author{
Xiaojuan Wang \\ College of Art and Design \\ Heihe University \\ Heihe, China
}

\begin{abstract}
With the promotion of Sino-Russian cooperative education projects, the educational resources of cooperatively constructed courses, teachers, teaching materials and facilities have been gradually improved, laying a solid foundation for the cultivation of art talents. However, in order to meet the requirements of the times and cultivate art-innovative talents, it is necessary to strengthen the reform of the discipline system and the construction of talent training models to ensure the quality of targeted art-based innovative talents and meet the needs of the society for innovative talents.
\end{abstract}

Keywords-Sino-Russian cooperative education; art talent; innovation-type; training mode

\section{INTRODUCTION}

Cultivation of art innovative talents against the background of Sino-Russian cooperative education should clarify the orientation and goals of talent cultivation, focus on the training plan for talents, carry out practice through introduction, going out, cultivating characteristics and creating brands, and directly promote the cultivation of compound and innovative talents from teaching.

\section{FEASIBILITY AND POSITIONING OF TALENT CULTIVATION}

After the baptism of the development of times, Chinese art has clearer pursuit and inheritance of national art. Russia's pursuit of art is also the inheritance of traditional art, which shows that the art values of both sides are highly consistent. Around this connected spiritual quality, Sino-Russian art education and cultural exchanges have become more frequent in recent years. In addition, China and Russia have maintained an attitude of mutual respect, seeking common ground while reserving differences, and complementing each

*Project: This thesis is the mid-term achievement of the 2017 Heilongjiang Art Science Planning Project "Study on the Innovation Model of Russian Teaching in Fine Arts major against the Background of SinoRussian Cooperative Education", Project No.: 2017D076; the mid-term achievement of 2017 School-level Teaching Reform Project "Research on the innovation model of Russian teaching in fine arts major against the Background Chinese-Russian Cooperative education, project number: xjg1736. other in cultural exchanges, which accelerates the pace of development of the Chinese and Russian art disciplines. Today, with the internationalization of education, we must give full play to the role of platform of Sino-Russian cooperative education project on the basis of local characteristics and needs, introduce advanced foreign teaching concepts, teaching methods, and international teaching ideas, and build an art innovative talent training mode with features and innovation.

\section{A. Feasibility Analysis}

With the advancement of Sino-Russian cooperative education project, the educational resources of cooperatively constructed courses, teachers, teaching materials, and facilities have been gradually improved, laying a solid foundation for the cultivation of art talents. Russia has advanced art education concepts, rich practical teaching achievements, a complete art discipline teaching system and innovative talent training mode. We can consolidate the foundation of Chinese and Russian disciplines and curriculum construction, and draw lessons from experience to create a new model of talent cultivation that belongs to the development of Chinese and Russian art disciplines. Through the Sino-Russian educational exchanges and discussion, we can scientifically decide art talent training model to form innovative talent training system conforming to the development of Chinese and Russian art disciplines.

There are many factors involved in the transnational exchange of art culture. We must actively focus on the cultivation of innovative talents, absorb the experience of Russian art education, and vigorously expand the connotation and depth of discipline construction. At the same time, we will strengthen our experience and summary; fully explore the innovative content of Chinese and Russian disciplines and curriculum systems with the help of geographical advantages and academic cooperation. Then we can further explore the cooperation in curriculum construction, and cultural exchanges, etc., provide a credible basis for the implementation of Sino-Russian art innovative talent training model and innovative experimental curriculum. 


\section{B. Positioning of Personnel Training}

The positioning of Sino-Russian joint education on art talents mainly focuses on social needs, professions, and courses and so on. First of all, we should develop the major according to the needs of the society, which must meet the changing trend of the social environment, and develop a distinctive and innovative talent training model centering on the needs of society. Secondly, we can set teaching courses according to the developed majors, and formulate the art teaching curriculum of Sino-Russian cooperation according to the training objectives of professional talents. The curriculum is formulated through the cultivation of the comprehensive ability of theoretical practice, to improve the students' skill level, and promote the joint teaching of Chinese and Russian art.

\section{THE ELEMENTS OF IMPROVING INNOVATIVE TALENT} TRAINING MODEL

\section{A. Environmental Factors}

There should be talent training environment and the teaching environment that meets the standards. The geographical environment of adjacency between China and Russia provides a high-quality geographical location for the cultivation of art talents.

\section{B. Course Factors}

We can also actively introduce foreign teaching courses, and lay a solid foundation for cultivation of innovative talents based on curriculum training objectives and content setting innovation. For the proportion of Russian curriculum resources, Russian courses need to account for one-third of the entire curriculum with a wide range of courses, involving ceramics, architectural design, sketching, decoration, character sketching, anatomy, oil painting, and folk art, etc., including sketches of figures, human body, still life, and plaster model. Professional core courses such as sketching and oil painting must account for about $30 \%$ of all core courses.

\section{Teacher Factors}

The introduced innovative courses requires foreign teachers to teach, and the foreign teacher courses must also account for about $30 \%$ of the total teaching hours to ensure the teaching quality of school projects and achieving the goal of innovative talent training.

\section{Textbook Factors}

Russian textbooks account for about one-third of the total textbooks, and we need to actively introduce Russian new textbooks to facilitate the teaching of Russian teachers. The supplementary books for Russian visual textbooks must be fully equipped to ensure the quality of Sino-Russian cooperative education.

\section{THE CONSTRUCTION OF ART INNOVATIVE TALENT TRAINING MODE}

In the cultivation of innovative art talents in SinoRussian cooperative education train, we must be innovative in teaching, pay attention to the mastery of students' art foundation when improving their artistic literacy and practical ability, and achieve a distinctive talent training model. To achieve a special training program, if we can't make independent innovation, we should adhere to the principle of introduction and going out to ensure that the teaching objectives are on track.

\section{A. Introducing}

With the continuous development of the social economy, the demand for art professionals of different levels or types is gradually increasing. In order to meet the objective needs of social development, various art colleges must strengthen professional education. From the previous scale construction to the connotation construction, we will increase the intensity of curriculum construction and the reform of teaching content to help transform the new talent training model. We should maximize the introduction of quality education resources of Russia, including textbooks, courses and faculty. Focusing on the actual teaching requirements, we will build a curriculum system with characteristics, standardized teaching links and comprehensive knowledge to ensure the effectiveness and standardization of course teaching [2].

First, we should actively introduce foreign teachers. We can employ Russian quality painters and foreign teacher in a long term, and establish targeted seminars and practical courses. While enriching the faculty structure of the SinoRussian cooperative education project, it will bring the modern teaching philosophy and teaching content to all teachers and students, and guarantee the optimization of the art professional system and the quality of joint teaching. We should focus on the professional training of the teacher team, and regularly launch training programs to update the teaching skills and concepts of the teacher team. Teachers are encouraged to go to various art colleges at home and abroad to study, so as to improve the faculty of Sino-Russian cooperative education through irregular training. When increasing the utilization rate of educational resources and promoting connotation construction, we can establish a teacher team with high quality and innovative awareness.

We should introduce Russian art education resources. We can actively introduce high-quality professional art textbooks. On the basis of it, we need to pay attention to the application of Russian original art textbooks and Russian textbooks in recent years can be applied reasonably. While introducing foreign art textbooks, it is also necessary to pay attention to the integration of Chinese and Russian textbooks. Textbooks are an important carrier for students to acquire knowledge. Teachers must clearly master the Chinese and Russian art creation techniques and actively develop art materials that are in line with innovative teaching. Besides, we can vigorously promote the innovative teaching of art selfediting textbooks, and make it the subject and major construction focus. In the construction of textbooks for art 
subjects, it is also necessary to learn from the development experience of Chinese and Russian art, such as painting art. In the art subject teaching, we actively introduce new skills and new knowledge to meet the comprehensive teaching needs of innovative talent training. We can use high-quality textbooks to provide services for the teaching with border features, education and teaching reform, and the optimization of curriculum, knowledge, and professional structure.

Second, we should set up a special curriculum system. In terms of curriculum development planning, it is necessary to investigate a large number of contemporary Chinese and Russian professional courses, clarify the objects, objectives and key points of innovative art talent training, and formulate an outline according to the plan. Focusing on the construction of Chinese and Russian art courses, as well as relevant materials collected by students, we can classify and read the Chinese and Russian contemporary art curriculum literature, make clear the teaching content, practice links and training objectives, and conduct case studies on Russian art innovation courses.

When we implement the teaching of art subjects according to Russian syllabus, we must pay attention to the depth of teaching and the extension of teaching content. In addition to the basic courses such as folk art, we offer courses of Russian pottery, modern painting, batik and paper composition, and make overall planning for architectural design, Russian sculpture, decoration and other special courses. Through comprehensive education such as fine art, art, design, etc., we can stimulate students' interest in learning, when helping students develop vision, knowledge, and aesthetics, etc., and promote students' innovative development. The curriculum reform of the art subject curriculum is the most direct reflection of the talent training ideas. The reform of the curriculum system must focus on the teaching objectives of cultivating creative innovation ability and styling expression ability, and rationally set the course category based on the quality education teaching standards and the actual professional teaching content. We should pay attention to the development of practical courses, adjust the class hour of practical courses and compulsory courses, focus on the refinement of theoretical teaching and the quality of practical courses and make practical courses and compulsory courses complement each other. Focusing on the needs of social and economic development, we will increase the adjustment of professional construction and professional structure, regularly organize professional education personnel, and rationally adjust the current syllabus, personnel training program, curriculum structure, talent positioning, and teaching objectives around the purpose of cooperative education and formulate an innovative teaching curriculum system for modern SinoRussian cooperative education projects.

Finally, we should set up a studio group. We can actively build campus and off-campus studio group, and set up studios, including oil painting human body creation, oil painting landscape creation, environmental art research, calligraphy, computer design, and lacquer painting creation and so on. We can promote the development of students' thinking over time, and use continuous learning and research to enhance self-creation ability. It is also indispensable for the optimization of practical teaching in schools. In practice, the introduction of education model with a large rotation and two small rotations achieves rotation education between enterprise and school. We can also hire a famous Russian artist as a guide to discuss the practical teaching process and content with the school teachers etc. and make personal demonstration in the school. They can organize students to participate in art creation, cultivate students' innovative ability, and pay more attention to the protection and development of students' individuality. The construction of the characteristics of practical courses and the pertinence of practical teaching content must be effectively combined with contemporary Russian creation to achieve diversified development of practice.

\section{B. Going out}

Western countries pay more attention to the cultivation of art talents. At the same time, they have built a variety of practice, practical teaching bases, and various practical places, which has made up for the lack of classroom teaching in art majors and develop the cultivation of innovative thinking of art students. China is in a groping and advanced stage in the cultivation of fine arts talents, so there is still a big gap between foreign countries. The construction and opening of the base has provided opportunities for SinoRussian cultural exchanges. The Sino-Russian cooperative education project has set up art practice creation, sketching bases and practical teaching bases throughout the country and parts of Russia. We can send students to the base to practice regularly to cultivate students' comprehensive ability in theory and practice, as well as the ability to create art.

\section{Cultivating Characteristics}

Taking the construction of characteristic courses as a breakthrough, we can promote the curriculum reform to be effective. Through teaching research, we carry out systematic, normative and efficient construction of art disciplines; actively develop training models that meet the requirements of innovative talents, as well as the cultivation model for fine art talents with high teaching quality, high teaching efficiency, and characteristics. In practice, we focus on the opening of resources such as teacher resources, teaching content, teaching materials, and teaching bases. In teaching, it is necessary to set up a professional and scientific teaching assessment method around the concept of quality education with students as the main body. At the same time, we should enrich the characteristics of teaching content, methods and means, and constantly improve the level of characteristic curriculum construction.

Sino-Russian cooperative education, continually innovate ways to condense more external wisdom based on the purpose of running a school with special characteristics, jointly applied for construction projects and scientific research projects with Russian experts and scholars, and realized the transformation of scale construction and connotation construction according to the project, which laid the foundation for innovation in the teaching and talent training model of cooperative education. The adjustment of 
the Russian foreign teaching structure has continuously optimized the teaching quality and teaching content, providing opportunities for the development of Sino-Russian cooperative education projects and injecting vitality into the development of the project. Various provincial philosophy and social science planning projects, landscape creation research, provincial humanities and social science research projects have introduced more foreign teachers, which have guaranteed the academic level and the improvement of educational service quality [3].

\section{Creating a Brand}

Art communication is unrestricted, and development is borderless. In recent years, with the constant collision between Chinese and Russian cultures, the Chinese and Russian art exchange platforms have become more mature, and various international painting design competitions, summit forums, and international exhibitions, etc. have been held regularly in joint schools, which provide convenience for Chinese and Russian art integration. At the same time, it is of practical significance to the expansion of the knowledge of teachers and students, the improvement of art cultivation, and the mastery of professional skills. It is also the creation of art education brands. In recent years, the Sino-Russian cooperative education project has launched and participated in the academic exchanges such as "National Year", "Language Year", "Chinese Year", "Chinese Painting Exhibition", "Celebrating the National Day", "Russian Oil Painting Master Training Class and Master Class Work Exhibition", "Sino-Russian-Korean Modern Art Festival", and "International Conference on Science and Practice" have brought vitality to the brand creation of Sino-Russian cooperation projects, and also provide a development platform for the cultivation of innovative talents in the context of Sino-Russian cooperative education

\section{CONCLUSION}

The construction of innovative and characteristic SinoRussian contemporary art disciplines is of great significance to the cultivation of art innovative talents against the background of Sino-Russian cooperation. In the reform of the talent training mode, it is necessary to pay full attention to the full use of Russian teaching resources, continuously introduce Russian art courses, and teachers, etc., and optimize the curriculum structure system and teaching mode to meet the talent needs of the Chinese and Russian contemporary art market. Studying the research of art innovation and compound talent training mode under the Sino-Russian cooperative education model is of great significance to making up for the shortage of Chinese and Russian talents and promoting the progress of Chinese and Russian contemporary art research.

\section{REFERENCES}

[1] Pan Hua. On the ways to realize the training target of tourism comprehensive talents under the Sino-Russian cooperative school model[J]. Journal of Heihe University, 2016, 7(4): 52-54.
[2] Zhang Dachun, Fan Hongdi. Research on Sino-Russian cooperative education in Heilongjiang Province to train ice and snow sports professionals[J]. Travel Overview (The Second Half of the Month), 2016(8).

[3] Lan Hao, He Xiaotao, Jin Ling. Research on Sino-Russian cooperative education against the background of the Belt and Road strategy[J]. Journal of Luoyang Normal University, 2017, 36(9): 23 26. 